\title{
DAMPAK PERKULIAHAN DARING TERHADAP PRESTASI BELAJAR MAHASISWA TEOLOGI SEKOLAH TINGGI TEOLOGI CIPANAS
}

\author{
Yudha Nata Saputra ${ }^{1}$ \\ ${ }^{1}$ Sekolah Tinggi Teologi Cipanas, Kementerian Agama, Jawa Barat \\ 1yudhanata99@gmail.com

\begin{tabular}{l} 
doi https://doi.org/10.36052/andragogi.v9i2.241 \\
Diterima: 30 September 2021 | Disetujui: 22 November 2021 | Dipublikasikan: 31 Desember 2021 \\
\hline
\end{tabular}

\begin{abstract}
Abstrak
Pandemi Covid-19 telah "memaksa", sektor pendidikan tidak terkecuali pendidikan tinggi keagamaan, seperti STT untuk mengubah kegiatan perkuliahan tatap muka ke dalam bentuk perkuliahan daring. Banyaknya kendala yang dihadapi perguruan tinggi dalam melaksanakan perkuliahan daring, seperti kurangnya penyerapan materi perkuliahan yang disampaikan dosen, sambungan internet yang jelek, sulitnya beradaptasi dengan perkuliahan daring. Menimbulkan kekuatiran akan berdampak kepada menurunnya prestasi belajar mahasiswa. Beberapa penelitian dampak perkuliahan daring terhadap prestasi belajar mahasiswa sudah dilakukan oleh beberapa perguruan tinggi, namun untuk perguruan tinggi keagamaan masih sangat jarang, sehingga perlu segera dilakukan penelitian berkaitan dengan dampak perkuliahan daring terhadap prestasi belajar mahasiswa di perguruan tinggi keagamaan. Tujuan penelitian ini, yaitu untuk menganalisa dampak perkuliahan daring terhadap prestasi belajar mahasiswa di sekolah tinggi teologi. Metode penelitian yang digunakan dalam peneltiian ini, yaitu metode eksperimen, dengan membandingkan rata-rata prestasi belajar mahasiswa sebelum pembelajaran daring dengan setelah pembelajaran daring. Hasil penelitian menunjukkan adanya perbedaan rata-rata prestasi belajar mahasiswa yang signifikan sebelum pembelajaran daring dengan setelah pembelajaran daring, di mana prestasi belajar mahasiswa setelah pembelajaran daring lebih tinggi dibandingkan sebelum pembelajaran daring.
\end{abstract}

Kata Kunci: perkuliahan daring, pandemi Covid-19, pendidikan tinggi, prestasi belajar

\begin{abstract}
The Covid-19 pandemic has "forced", the education sector is no exception for religious higher education, such as STT to change face-to-face lectures into online lectures. There are many obstacles faced by universities in carrying out online lectures, such as the lack of absorption of lecture material delivered by lecturers, poor internet connections, difficulty adapting to online lectures. Generating worry will have an impact on decreasing student achievement. Several studies on the impact of online lectures on student achievement have been carried out by several universities, but for religious universities it is still very rare, so it is necessary to immediately conduct research related to the impact of online lectures on student achievement in religious universities. The purpose of this study is to analyze the impact of online lectures on student achievement in theological colleges. The research method used in this research, namely the experimental method, by comparing the average student achievement before online learning and after online learning. The results showed that there was a significant difference in the average student achievement before online learning and after online learning, where student learning achievement after online learning was higher than before online learning.
\end{abstract}

Keywords: online lectures, Covid-19 pandemic, higher education, learning achievement. 


\section{PENDAHULUAN}

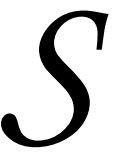

ekolah Tinggi Teologi (STT), merupakan salah satu institusi pendidikan tinggi keagamaan yang terkena dampak pandemi Covid-19. Akibatnya "memaksa" STT untuk mengubah perkuliahan tatap muka menjadi perkuliahan daring. Hal ini sejalan dengan Surat Edaran Kemendikbud Nomor 36962/MPK.A/HK/2020 tentang Pembelajaran secara Daring dan Bekerja dari Rumah dalam Rangka Pencegahan Penyebaran COVID-19, salah satunya ditujukan kepada seluruh Pimpinan Perguruan Tinggi Negeri/Swasta. Salah satu poin penting dari surat edaran ini, yaitu memberlakukan pembelajaran dari rumah bagi siswa dan mahasiswa (Mendikbud, 2020). Demikian pula Menteri Agama pada waktu itu, Fachrul Razi meminta agar Perguruan Tinggi Keagamaan (PTK) mengambil kebijakan yang tegas untuk mencegah penyebaran virus Corona dengan memberlakukan kegiatan belajar mengajar jarak jauh, termasuk agar pengelola perguruan tinggi agama dan keagamaan bersinergi dan menyesuaikan dengan kebijakan Kemendibud dan Pemerintah Daerah (Kontri, 2020). Hingga saat ini perkuliahan daring masih berjalan, meskipun skenario perkuliahan tatap muka sudah dirancang dengan memberikan prioritas vaksinasi kepada tenaga pendidik, dengan harapan perkuliahan tatap muka bisa segera dilaksanakan.

Pandemi Covid-19 telah "memaksa", sektor pendidikan tidak terkecuali pendidikan tinggi keagamaan, seperti STT untuk mengubah kegiatan perkuliahan tatap muka ke dalam bentuk perkuliahan daring. Direktur Jenderal Pendidikan Tinggi Kementerian Pendidikan dan Kebudayaan, Nizam mengatakan sudah 98\% perguruan tinggi di Indonesia melakukan pembelajaran secara daring (98 Persen Kampus PJJ Daring, Kemdikbud Klaim Mahasiswa Siap, n.d.). Berdasarkan survei yang dilakukan Kemendikbud terhadap 237.193 responden dari total mahasiswa 8.325.013 mahasiswa yang terdaftar di Pangkalan Data Pendidikan Tinggi, lebih dari $60 \%$ mahasiswa siap dengan kuliah daring. Mayoritas mahasiswa, sebesar 45,56\% menilai kualitas perkuliahan daring yang sudah dilaksanakan berjalan baik. Sementara $30.85 \%$ responden mengeluhkan konektivitas internet yang buruk. Meskipun konektivitas internet buruk namun menurut Nizam, hal ini tidak banyak berdampak pada capaian pembelajaran mahasiswa (98 Persen Kampus PJJ Daring, Kemdikbud Klaim Mahasiswa Siap, n.d.). Hal ini bisa terjadi karena kemampuan belajar mandiri yang dimiliki oleh mahasiswa turut menentukan keberhasilan dari pembelajaran daring yang dilakukan di samping ketersediaan perangkat pembelajaran yang mendukung.

Sementara itu hasil penelitian Dewantara dan Nurgiansah, menemukan bahwa 79\% mahasiswa Universitas PGRI Yogyakarta justru menginginkan pembelajaran tatap muka dan hanya $1 \%$ saja yang menginginkan pembelajaran daring. Alasannya karena tidak semua dosen memiliki kemampuan teknologi informasi yang memadai, koneksi jaringan internet yang sering bermasalah dan tidak semua mata kuliah dapat disampaikan secara online, seperti mata kuliah praktek (Nurgiansah \& Dewantara, 2021). Dengan berbagai alasan ini, maka pembelajaran daring yang selama ini dilaksanakan dinilai tidak cukup efektif. Hasil penelitian yang tidak jauh berbeda, dilakukan oleh Widiyono mengemukakan bahwa perkuliahan daring yang dilaksanakan pada mahasiswa prodi PGSD FTIK UNISNU Jepara tidak cukup efektif. Terdapat 75,81\% mahasiswa yang kurang paham terhadap materi yang disampaikan dan $66,67 \%$ mahasiswa mengatakan bahwa sinyal internet yang digunakan dalam pembelajaran daring 
masih berada pada kategori sedang dan hanya $5.91 \%$ saja yang mengatakan bahwa sinyal internet kuat (Widiyono, 2020). Tidak optimalnya penyampaian materi akibat kendala jaringan dan banyaknya tugas yang harus dikerjakan oleh mahasiswa menjadi penyebab banyaknya mayoritas mahasiswa yang menginginkan perkuliahan tatap muka.

Meskipun beberapa hasil penelitian menunjukkan bahwa perkuliahan daring dinilai tidak efektif, tapi beberapa penelitian justru menemukan adanya pengaruh positif pembelajaran daring terhadap prestasi belajar mahasiswa. Limbong, menemukan bahwa secara umum adanya peningatan IPS mahasiswa UNAI tingkat dua ke atas, kendala dihadapi hanya oleh mahasiswa tingkat satu (baru). Hal ini menunjukkan bahwa dosen dan mahasiswa dapat bekerja sama dalam mengatasi kendala pembelajaran daring yang sudah dilaksanakan (Limbong, 2020). Temuan yang sama, diungkapkan oleh Purnawinadi melalui penelitiannya kepada mahasiswa keperawatan tahap akademik. Terdapat peningkatan prestasi belajar mahasiswa sebelum dan saat pandemi Covid-19 yang signifikan. Hasil penelitiannya menunjukkan bahwa lebih banyak mahasiswa yang berprestasi pada saat pandemi dibandingkan sebelum, artinya selama masa pandemi mahasiswa masih mampu memiliki peluang untuk mencapai prestasi yang tinggi dengan menjaga motivasi belajar mereka (Purnawinadi, 2021). Tetapi hasil penelitian yang berbeda, diungkapkan Silaban yang menemukan adanya penurunan Indeks Prestasi Akademik Mahasiswa Penerima Beasiswa Bidik Misi di UNIHAZ sebesar 0.07, dari yang sebelumnya rata-rata IPK 3,31 menjadi 3.24 selama pandemi Covid-19 ini (Silaban et al., 2021). Dengan melihat kenyataan ini, bisa dikatakan bahwa perkuliahan daring yang dilakukan oleh sebagian besar perguruan tinggi, memberikan hasil yang bervariasi terhadap prestasi belajar mahasiswa.

Dalam kontek manajamen mutu pendidikan, prestasi belajar mahasiswa yang diukur dengan Indeks Prestasi Belajar merupakan salah satu ukuran keberhasilan mutu pendidikan. Mahasiswa program diploma dan sarjana dinyatakan lulus jika Indeks Prestasi Kumulatif (IPK) lebih besar atau sama dengan 2,00. Sedangkan mahasiswa program profesi, program spesialis, program magister dan program doktor dinyatakan lulus jika IPK lebih besar atau sama dengan 3,00 (Pendidikan et al., 2020). Prestasi belajar mahasiswa yang diukur dalam bentuk hasil belajar yang dinyatakan dalam bentuk IPK menjadi penting karena merupakan salah satu output pendidikan tinggi, hal ini seperti yang dinyatakan Bank Dunia sebagaimana dikutip oleh Sedarmayanti bahwa Keluaran pendidikan adalah pencapaian prestasi belajar murid yang meliputi pengetahuan, keterampilan, tingkah laku, dan sikap yang diukur dengan tes, hasil ujian dan sejenisnya (Sedarmayanti, 2009). Melalui nilai IPK, pencapaian prestasi belajar mahasiswa ditentukan keberhasilannya, dan menjadi pedoman bagi pemerintah, orangtua, dan pengguna lulusan untuk mengambil keputusan.

Beberapa hasil penelitian terdahulu terkait dengan perkuliahan daring yang dilaksanakan selama pandemi Covid-19, telah banyak dilakukan di beberapa perguruan tinggi umum, sementara itu penelitian terkait perkuliahan daring yang dilakukan di sejumlah peguruan tinggi keagamaan Kristen, seperti STT masih sangat jarang dilakukan. Padahal dengan jumlah perguruan tinggi keagamaan Kristen sebanyak 364 sekolah (Saputra, 2020a), maka penting untuk mendapatkan gambaran tentang pelaksanaan perkuliahan daring yang dilakukan selama pandemi Covid-19, sehingga dapat diambil kebijakan yang tepat. Terutama 
berkaitan dengan dampak pembelajaran daring terhadap prestasi belajar mahasiswa, mengingat prestasi belajar mahasiswa merupakan salah satu ukuran keberhasilan pencapaian mutu pendidikan, yang bermanfaat bagi berbagai pihak dalam mengambil keputusan. Tentunya mengingat STT sendiri merupakan salah satu perguruan tinggi yang terdampak oleh pandemi Covid-19, maka perlu segera dilakukan penelitian terhadap prestasi belajar mahasiswanya, sehingga bisa diambil kebijakan yang tepat. STT Cipanas sendiri sebagai salah satu STT tertua di Jawa Barat telah dan masih melaksanakan pembelajaran daring dalam rangka mengantisipasi pandemi Covid-19 yang belum bisa dipastikan berakhirnya. Melihat situasi ini, maka rumusan masalah dalam penelitian ini yaitu "Bagaimana dampak pembelajaran daring terhadap prestasi belajar mahasiswa di STT Cipanas?". Tujuan dari penelitian ini yaitu menganalisis dampak pembelajaran daring terhadap prestasi belajar mahasiswa di STT Cipanas. Hipotesis dalam penelitian ini, yaitu terdapat perbedaan prestasi belajar mahasiswa yang signifikan pada saat perkuliahan tatap muka dengan pada saat perkuliahan daring di STT Cipanas.

\section{METODE PENELITIAN}

Pendekatan penelitian yang digunakan adalah pendekatan kuantitatif dengan menggunakan metode eksperimen. Hal ini sesuai dengan tujuan penelitian ini, yaitu untuk menguji hipotesis tentang perbedaan prestasi belajar mahasiswa di STT Cipanas pada saat perkuliahan tatap muka dengan pada saat perkuliahan daring. Adapun yang menjadi sampel dalam penelitian ini yaitu, mahasiswa tingkat dua dan tiga yang berjumlah 35 orang. Sementara mahasiswa tingkat satu pada saat penelitian ini dilakukan belum pernah melaksanakan perkuliahan tatap muka sedangkan mahasiswa tingkat empat sedang menyusun skripsi. Prestasi belajar mahasiswa dalam penelitian ini diukur oleh Indeks Prestasi Belajar mahasiswa. Teknik statistik yang digunakan adalah uji $\mathrm{t}$ untuk sampel yang berpasangan (Paired Sample T-Test), hal ini dilakukan untuk menguji ada tidaknya perbedaan prestasi belajar mahasiswa pada saat perkuliahan tatap muka dengan pada saat mengikuti perkulihan daring. Dalam rangka keakuratan perhitungan, maka digunakan software SPSS ver 23.00.

\section{TEMUAN DAN PEMBAHASAN}

\section{Temuan}

Hasil penelitian kepada 35 responden tentang dampak perkuliahan daring terdapat prestasi belajar mahasiswa di STT Cipanas, dengan menggunakan uji $\mathrm{t}$ untuk sampel berpasangan (Paired Sample T-Test), dapat diamati di bawah ini.

Tabel 1. Paired Samples Statistics

\begin{tabular}{llcccc}
\hline & & Mean & N & Std. Deviation & Std. Error Mean \\
\hline Pair 1 & Prestasi_Kuliah_Offline & 3.0697 & 36 & .36225 & .06038 \\
& Prestasi_Kuliah_Online & 3.2653 & 36 & .37999 & .06333 \\
\hline
\end{tabular}

Berdasarkan hasil pengolahan data di atas, dapat diketahui bahwa rata-rata prestasi belajar mahasiswa sebelum perkuliahan daring adalah 3.0697, sedangkan rata-rata prestasi belajar mahasiswa setelah mengikuti perkuliahan daring sebesar 3.2653 . 
Tabel 2. Paired Samples Correlation

\begin{tabular}{llccc}
\hline & & N & Correlation & Sig. \\
\hline Pair 1 & $\begin{array}{l}\text { Prestasi_Kuliah_Offline \& } \\
\text { Prestasi_Kuliah_Online }\end{array}$ & 36 & .542 & .001 \\
\hline
\end{tabular}

Hasil Paired sampels correlation menunjukkan hasil korelasi antara prestasi belajar sebelum perkuliahan daring dan prestasi belajar setelah perkuliahan daring, sebesar 0.542 dengan nilai signifikan 0.001 artinya terdapat hubungan yang signifikan antara prestasi belajar mahasiswa sebelum perkuliahan daring dan setelah perkuliahan daring

Tabel 3. Paired Samples Test

\begin{tabular}{|c|c|c|c|c|c|c|c|c|c|}
\hline & & \multicolumn{5}{|c|}{ Paired Differences } & \multirow[b]{3}{*}{$\mathbf{t}$} & \multirow[b]{3}{*}{ df } & \multirow{3}{*}{$\begin{array}{l}\text { Sig. (2- } \\
\text { tailed) }\end{array}$} \\
\hline & & \multirow[b]{2}{*}{ Mean } & \multirow{2}{*}{$\begin{array}{c}\text { Std. } \\
\text { Deviation }\end{array}$} & \multirow{2}{*}{$\begin{array}{l}\text { Std. Error } \\
\text { Mean }\end{array}$} & \multicolumn{2}{|c|}{$\begin{array}{c}95 \% \text { Confidence } \\
\text { Interval of the } \\
\text { Difference }\end{array}$} & & & \\
\hline & & & & & Lower & Upper & & & \\
\hline $\begin{array}{l}\text { Pair } \\
1\end{array}$ & $\begin{array}{l}\text { Prestasi_Kuliah_ } \\
\text { Offline - } \\
\text { Prestasi_Kuliah_ } \\
\text { Online }\end{array}$ & -.19556 & .35558 & .05926 & -.31587 & -.07524 & -3.300 & 35 & .002 \\
\hline
\end{tabular}

Hipotesis

$\mathrm{HO}$ : Rata-rata prestasi belajar mahasiswa sebelum perkuliahan daring sama dengan rata-rata prestasi belajar mahasiswa setelah perkuliahan daring.

$\mathrm{Ha}$ : Rata-rata prestasi belajar mahasiswa sebelum perkuliahan daring berbeda dengan rata-rata prestasi belajar mahasiswa setelah perkuliahan daring.

Hasil t-hitung menunjukkan -3.300 dengan $P$ value $0.002<0.05(\alpha)$, artinya rata-rata prestasi belajar mahasiswa sebelum perkuliahan daring berbeda dengan setelah perkuliahan daring. Nilai negatif pada t-hitung menunjukkan nilai awal lebih rendah dari nilai berikutnya, artinya prestasi belajar mahasiswa sebelum perkuliahan daring lebih rendah dibandingkan setelah perkuliahan daring.

\section{Pembahasan}

Temuan hasil penelitian ini menunjukkan adanya peningkatan prestasi belajar mahasiswa sebelum dan sesudah perkuliahan daring. Nilai rata-rata IPS (Indeks Prestasi Semester) mahasiswa sebelum perkuliahan daring sebesar 3.0697, dan nilai rata-rata IPS mahasiswa setelah perkuliahan daring menjadi sebesar 3.2653, terjadi peningkatan nilai ratarata IPS mahasiswa sebesar 0.1956. Temuan ini sesuai dengan hasil penelitian Limbong, yang menemukan bahwa secara umum adanya peningatan IPS mahasiswa UNAI tingkat dua ke atas, kendala dihadapi hanya oleh mahasiswa tingkat satu (baru). Hal ini menunjukkan bahwa dosen dan mahasiswa dapat bekerja sama dalam mengatasi kendala pembelajaran daring yang sudah dilaksanakan (Limbong, 2020). Salah satu kendala perkuliahan daring adalah berkaitan dengan 
penyampaian materi oleh dosen, penelitian Ningsih menemukan sebesar 24,2\% responden mengatakan bahwa penjelasan dosen kurang maksimal (Ningsih, 2020). Hal yang sama dengan penelitian Dewantara dan Nurgiansah menemukan bahwa sebesar $79 \%$ responden merasakan penyampaian materi pembelajaran oleh dosen sangat kurang, hal ini bisa terjadi karena selama perkuliahan daring dosen melakukan pemadatan materi, dan mengurangi jumlah pertemuan tatap muka (Nurgiansah \& Dewantara, 2021). Pemadatan materi oleh dosen selama perkuliahan daring, sebetulnya tidak jadi masalah, jika materi yang dipilih merupakan materi esensial, sehingga capaian pembelajaran dapat tetap tercapai. Di samping itu dalam perkuliahan daring, maka penilaian terhadap hasil lebih penting daripada penilaian terhadap proses belajar, sehingga dosen bisa lebih kreatif dalam melaksanakan pembelajaran daring, misalnya saja menggunakan metode pembelajaran berbasis proyek. Sementara di STT Cipanas sendiri, meskipun perkuliahan dilakukan secara daring namun tetap diupayakan agar dosen tetap dapat memenuhi bobot pertemuan yang telah ditentukan.

Di samping persoalan penerimaan materi, kendala dalam perkuliahan daring yaitu akses internet. Survei yang dilakukan oleh Kemendikbud menemukan bahwa 30,85\% responden mengeluhkan konektivitas internet yang buruk (98 Persen Kampus PJJ Daring, Kemdikbud Klaim Mahasiswa Siap, n.d.). Meskipun konektivitas menjadi persoalan yang memang dihadapi mayoritas mahasiswa yang mengikuti perkuliahan daring, namun faktor lain seperti kesiapan belajar mandiri mahasiswa menjadi salah satu faktor penting dalam keberhasilan penyelenggaraan perkuliahan daring. Nizam mengatakan bahwa kendala konektivitas tidak banyak berdampak kepada capaian pembelajaran, karena capaian pembelajaran berbanding lurus dengan kesiapan mahasiswa dalam melaksanakan aktivitas pembelajaran daring (98 Persen Kampus PJJ Daring, Kemdikbud Klaim Mahasiswa Siap, n.d.). Hal ini penting, karena peran mahasiswa dalam melaksanakan perkuliahan daring menjadi jauh lebih besar dibandingkan ketika melakukan perkuliahan tatap muka sehingga kesiapan belajar mandiri mahasiswa menjadi salah satu faktor penentu keberhasilan perkuliahan daring (Saputra, 2021). Terjadinya peningkatan prestasi belajar mahasiswa di STT Cipanas dibuktikan dengan tingkat kesiapan belajar mandiri mahasiswa yang sudah berada pada tahap sedang. Penelitian tentang kesiapan belajar mandiri kepada 78 mahasiswa STT Cipanas menemukan bahwa kesiapan belajar mandiri mahasiswa sudah berada pada tahap sedang (Saputra, 2021). Meskipun kesiapan belajar mandiri mahasiswa STT Cipanas masih berada pada tahap sedang, namun ini jauh lebih baik sehingga lebih mudah untuk melakukan perkuliahan daring dibandingkan jika mahasiswa tidak memiliki kesiapan belajar mandiri. Karena mahasiswa STT Cipanas sudah memiliki kesiapan belajar mandiri tahap sedang maka perkuliahan daring yang sudah dilaksanakan selama ini, terbukti tidak menurunkan prestasi belajar mereka namun sebaliknya prestasi belajar dapat tetap meningkat meskipun perkuliahan dilakukan secara daring. Adanya pengaruh kesiapan belajar mandiri mahasiswa terhadap prestasi belajar mahasiswa selama perkuliahan daring dikemukakan oleh Winata, sebesar 42,2\% prestasi belajar mahasiswa dapat dijelaskan oleh kemandirian belajar dan kedisplinan belajar mahasiswa (Winata et al., 2021).

Temuan yang tidak berbeda jauh, diungkapkan oleh Purnawinadi melalui penelitiannya kepada mahasiswa keperawatan 
tahap akademik. Terdapat peningkatan prestasi belajar mahasiswa sebelum dan saat pandemi Covid-19 yang signifikan. Hasil penelitiannya menunjukkan bahwa lebih banyak mahasiswa yang berprestasi pada saat pandemi dibandingkan sebelum, artinya selama masa pandemi mahasiswa masih mampu memiliki peluang untuk mencapai prestasi yang tinggi dengan menjaga motivasi belajar mereka (Purnawinadi, 2021). Tidak dapat dipungkiri bahwa motivasi belajar merupakan salah satu faktor penting dalam menentukan prestasi belajar seseorang. Penelitian Elis Mediawati menemukan adanya pengaruh motivasi belajar terhadap prestasi belajar mahasiswa sebesar $12.2 \%$ (Mediawati, 2010). Demikian juga penelitian Kasih Haryo Basuki yang menemukan adanya pengaruh langsung motivasi belajar terhadap prestasi belajar sebesar 8.24\% (Basuki, 2015). Keke Aritonang mengatakan bahwa seseorang dapat belajar atau tidak bergantung kepada kebutuhan dan motivasinya (Aritonang, 2008). Adanya peningkatan prestasi belajar mahasiswa meskipun dalam perkuliahan daring menunjukkan bahwa selama mahasiswa tersebut memiliki motivasi belajar yang tinggi, sehingga hambatan yang dialami selama perkuliahan daring, tetap dapat diatasi dan tidak sampai menganggu prestasi belajarnya. Kenyataan ini didukung oleh penelitian terhadap motivasi belajar mahasiswa STT Cipanas sebelumnya, yang memang berada pada kategori tinggi (Saputra, 2020b).

Tetapi hasil penelitian yang berbeda, diungkapkan Silaban yang menemukan adanya penurunan Indeks Prestasi Akademik Mahasiswa Penerima Beasiswa Bidik Misi di UNIHAZ sebesar 0.07, dari yang sebelumnya rata-rata IPK 3,31 menjadi 3.24 selama pandemi Covid-19 ini (Silaban et al., 2021). Menurut Silaban, kemampuan adaptasi dengan lingkungan belajar menjadi faktor penyebab keberhasilan dalam melaksanakan perkuliahan daring (Silaban et al., 2021). Slameto mengatakan bahwa belajar dipengaruhi oleh faktor internal (jasmani, pskilogis, kelelahan) dan faktor eskternal (keluarga, sekolah, masyarakat) (Slameto, 2010). Sehingga bisa dikatakan bahwa adanya perbedaan hasil penelitian ini bisa disebabkan oleh karakteristik responden yang berbeda. Hal ini sejalan dengan hasil survei yang dilakukan oleh Kemendikbud bahwa memang belum semua mahasiswa memiliki kesiapan dalam melaksanakan perkuliahan daring, baru $60 \%$ mahasiswa yang siap melaksanakan perkuliahan daring (98 Persen Kampus PJJ Daring, Kemdikbud Klaim Mahasiswa Siap, n.d.). Kemampuan adaptasi dengan lingkungan belajar yang baru, dari perkuliahan tatap muka beralih ke perkuliahan daring memang membutuhkan kesiapan belajar dari mahasiswa. Kesiapan belajar mahasiswa menjadi penting, karena adanya perbedaan karakteristik antara perkuliahan tatap muka dengan perkuliahan daring.

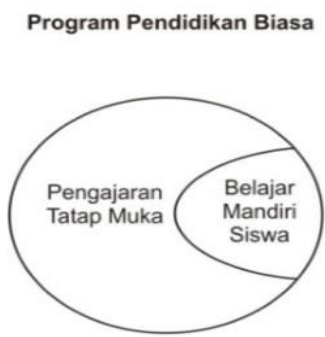

Program Pendidikan Jarak Jauh

Gambar 1. Perbedaan Pendidikan Tatap Muka dan Pendidikan Jarak Jauh (Suparman dan Zuhairi 2004) (Kusmawan, 2016)

Dalam perkuliahan tatap muka, aktivitas belajar mandiri mahasiswa jauh lebih sedikit jika dibandingkan dengan perkuliahan daring, yang menuntut adanya aktivitas belajar mandiri yang lebih besar. Hal ini terjadi karena interaksi dengan lingkungan sosial dalam perkuliahan daring jauh lebih sedikit dibandingkan dengan perkuliahan tatap muka 
akibatnya diperlukan kesiapan belajar mandiri mahasiswa yang lebih besar dibandingkan pada saat perkuliahan tatap muka (Saputra, 2021). Hal inilah seperti yang dikatakan Nizam, bahwa meskipun koneksi internet merupakan salah satu kendala dalam pembelajaran daring namun dampaknya terhadap capaian pembelajaran sedikit, karena capaian pembelajaran mahasiswa lebih banyak dipengaruhi oleh kesiapan belajar mahasiswa (98 Persen Kampus PJJ Daring, Kemdikbud Klaim Mahasiswa Siap, n.d.). Mahasiswa yang memiliki kesiapan belajar mandiri yang tinggi akan lebih mampu berprestasi dalam perkuliahan daring dibandingkan dengan mahasiswa yang kesiapan belajar mandirinya lebih rendah. Hasil penelitian Darmayanti menemukan terdapat korelasi positif sebesar 0.24 antara kesiapan belajar mandiri mahasiswa dengan prestasi belajar mahasiswa pada mahasiswa yang menempuh pendidikan jarak jauh di Universitas Terbuka (Darmayanti, 2005).

Banyaknya mahasiswa yang mengeluhkan mengenai penyampaian materi yang kurang selama perkuliahan daring, seperti terungkap dari hasil penelitian Ningsih yang menemukan sebesar $24,2 \%$ responden mengatakan bahwa penjelasan dosen kurang maksimal (Ningsih, 2020). Hasil penelitian Irnanda yang menemukan bahwa atribut pemahaman materi merupakan aspek yang paling berpengaruh terhadap menurunnya prestasi belajar mahasiswa selama pandemi (Irnanda et al., 2021). Demikian juga dengan penelitian Dewantara dan Nurgiansah menemukan bahwa sebesar $79 \%$ responden merasakan penyampaian materi pembelajaran oleh dosen sangat kurang, hal ini bisa terjadi karena selama perkuliahan daring dosen melakukan pemadatan materi, dan mengurangi jumlah pertemuan tatap muka (Nurgiansah \& Dewantara, 2021). Ketergantungan mahasiswa kepada materi yang disampaikan dosen dalam perkuliahan daring menunjukkan kurangnya kesiapan belajar mandiri mahasiswa, yang berdampak kepada menurunnya prestasi belajar.

Begitu pula dengan beberapa hasil penelitian yang menginginkan perkuliahan tatap muka dilaksanakan daripada perkuliahan daring. Penelitian Dewantara dan Nurgiansah yang menyebutkan bahwa $79 \%$ responden menginginkan perkuliahan tatap muka, dan hanya $1 \%$ responden yang menginginkan perkuliahan daring (Nurgiansah \& Dewantara, 2021). Penelitian Ningsih juga mengemukakan bahwa 93.5\% memilih belajar di kelas dan hanya $6.5 \%$ yang memilih belajar di rumah (Ningsih, 2020). Keinginan untuk memilih perkuliahan tatap muka dibandingkan daring karena sejumlah kendala yang dihadapi seperti efektivitas penyampaian materi dan hambatan koneksi internet menunjukkan kesiapan belajar mandiri mahasiswa yang masih rendah sehingga menyulitkan dalam proses adaptasi dari perkuliahan tatap muka ke perkuliahan daring.

Kesulitan yang dihadapi oleh mahasiswa pada saat perkuliahan daring, dikemukakan dalam hasil penelitian Annur, yaitu tidak terbiasa dengan kelas online, kondisi lingkungan rumah yang tidak kondusif, tugas perkuliahan daring yang lebih banyak, kesulitan membagi waktu antara belajar dan bekerja, terpaksa mengikuti perkuliahan daring, materi perkuliahan yang dianggap sulit (Annur \& Hermansyah, 2020). Sementara itu, kemampuan mahasiswa dalam belajar mandiri dibentuk oleh beberapa faktor yaitu Otonomi Diri, Pengelolaan Diri, Kebutuhan Belajar Mandiri dan Kontrol Belajar terhadap Pembelajaran (Candy, 1991), kesulitan membagi waktu antar belajar dan bekerja menunjukkan kurangnya kemampuan mahasiswa dalam pengelolaan diri. 
Keterpaksaan mengikuti perkuliahan daring karena situasi pandemi menunjukkan tingkat kebutuhan belajar mandiri yang rendah, karena seseorang yang memiliki kebutuhan belajar mandiri yang tinggi tidak pernah merasa terpaksa dalam belajar. Kemudian materi pelajaran yang dianggap sulit, menunjukkan kurangnya kontrol belajar terhadap pembelajaran, seseorang yang memiliki kesiapan belajar mandiri yang tinggi mampu menentukan materi yang dibutuhkannya.

Hasil penelitian yang berbeda dikemukakan oleh Widiyono yang menemukan 23,66\% mahasiswa menginginkan perkuliahan daring, sebesar 13,44\% menginginkan perkuliahan luring dan $62.90 \%$ menginginkan perkuliahan campuran (Widiyono, 2020). Rendahnya keinginan mahasiswa untuk mengikuti perkuliahan daring menunjukkan adanya kesiapan belajar mandiri mahasiswa yang tinggi. Karena sekalipun perkuliahan daring memiliki kendala namun mahasiswa tetap dapat merasakan manfaat dari perkuliahan daring. Meskipun hasil penelitian Ningsih menunjukkan bahwa mayoritas mahasiswa menginginkan pembelajaran tatap muka tapi manfaat pembelajaran daring tetap dirasakan oleh mahasiswa. Terdapat 40,3\% mahasiswa yang merasakan kemudahan untuk belajar dimana saja dan kapan saja, menjadi lebih peka terhadap teknologi pembelajaran sebesar 22.6\%, sebesar $17.7 \%$ mahasiswa dapat mengatur gaya belajarnya, sebesar 9,7\% merasakan adanya efisiensi waktu, sebesar 8,1\% merasakan belajar yang lebih tenang dan fokus (Ningsih, 2020). Munculnya kesadaran akan manfaat perkuliahan daring dari mahasiswa menunjukkan bahwa pada dasarnya mahasiswa mampu mengikuti perkuliahan daring, jika saja kendala-kendala yang dihadapi selama melaksanakan perkuliahan daring dapat diatasi, termasuk salah satunya dengan mengupayakan untuk meningkatkan kesiapan belajar mandiri mahasiswa. Jika kendala perkuliahan daring dapat diatasi maka keberhasilan belajar mahasiswa dalam mengkikuti perkuliahan daring yang ditunjukkan dengan meningkatnya prestasi belajar dalam bentuk capaian Indeks Prestasi Belajar akan dapat meningkat sekalipun dalam kondisi perkuliahan daring.

\section{PENUTUP}

\section{Simpulan}

Berdasarkan hasil penelitian, maka dapat ditarik simpulan bahwa terdapat perbedaan prestasi belajar mahasiswa di STT Cipanas sebelum melaksanakan perkuliahan daring dan setelah melaksanakan perkuliahan daring. Hasil t-hitung menunjukkan -3.300 dengan $\mathrm{P}$ value $0.002<0.05(\alpha)$, artinya rata-rata prestasi belajar mahasiswa sebelum perkuliahan daring berbeda dengan setelah perkuliahan daring. Nilai rata-rata prestasi belajar mahasiswa sebelum perkuliahan daring sebesar 3.0697 sedangkan rata-rata prestasi belajar mahasiswa setelah mengikuti perkuliahan daring sebesar 3.2653, artinya terdapat peningkatan prestasi belajar mahasiswa setelah mengikuti perkuliahan daring sebesar 0.1956 .

\section{Rekomendasi}

Supaya prestasi mahasiswa di STT Cipanas selama mengikuti perkuliahan daring dapat terus ditingkatkan maka kendala-kendala selama mengikuti perkuliahan daring perlu segera diatasi, jika tidak maka prestasi belajar mahasiswa selama mengikuti perkuliahan daring tidak akan meningkat. 


\section{DAFTAR PUSTAKA}

98 Persen Kampus PJJ Daring, Kemdikbud Klaim Mahasiswa Siap. (n.d.). Retrieved June 20, 2021, from https://www.cnnindonesia.com/nasional/20200903012249-20-542198/98-persen-kampus-pjj-daringkemdikbud-klaim-mahasiswa-siap

Annur, M. F., \& Hermansyah. (2020). ANALISIS KESULITAN MAHASISWA PENDIDIKAN MATEMATIKA DALAM PEMBELAJARAN DARING PADA MASA PANDEMI COVID-19. Jurnal Kajian, Penelitian Dan Pengembangan Pendidikan, 11(2), 195-201.

Aritonang, K. (2008). Minat dan Motivasi dalam Meningkatkan Hasil Belajar Siswa. Jurnal Pendidikan Penabur, 10, 11-21. https://s3.amazonaws.com/academia.edu.documents/35904799/Hal._11-

21_Minat_dan_motivasi_belajar.pdf?AWSAccessKeyld =AKIAIWOWYYGZ2Y53UL3A\&Expires $=154664770$ 9\&Signature =f7H1 KwZM7hFoPxbWqf22INRogqY\%3D\&response - content-disposition $=$ inline\%3B filename\%3DMinat_da

Basuki, K. H. (2015). Pengaruh Kecerdasan Spiritual dan Motivasi Belajar terhadap Prestasi Belajar Matematika. Formatif: Jurnal Ilmiah Pendidikan MIPA, 5(2), 120-133. https://doi.org/10.30998/formatif.v5i2.332

Candy, P. C. (1991). Self-direction for Lifelong Learning , A Comprehensive to Theory and Practice. Jossey-Bass Inc.

Darmayanti, T. (2005). Efektivitas Intervensi Keterampilan Self-Regulated Learning dan Keteladanan dalam Meningkatkan Kemampuan Belajar Mandiri dan Prestasi Belajar Mahasiswa Pendidikan Jarak Jauh. Universitas Indonesia.

Irnanda, K. F., Hartama, D., \& Windarto, A. P. (2021). Analisa Klasifikasi C4 . 5 Terhadap Faktor Penyebab Menurunnya Prestasi Belajar Mahasiswa Pada Masa Pandemi. Jurnal Media Informatika Budidarma, 5, 327-331. https://doi.org/10.30865/mib.v5i1.2763

Kontri. (2020). Menag Minta Pimpinan PTK Ambil Langkah Tegas Cegah Corona. Kementerian Agama. https://kemenag.go.id/berita/read/513018/menag-minta-pimpinan-ptk-ambil-langkah-tegas-cegahcorona

Kuliah Tatap Muka Bisa Dimulai Juli 2021, Ini Penjelasan Ditjen Dikti Halaman all - Kompas.com. (n.d.). Retrieved June 22, 2021, from https://www.kompas.com/tren/read/2021/03/09/133802465/kuliah tatap-muka-bisa-dimulai-juli-2021-ini-penjelasan-ditjen-dikti?page=all

Kusmawan, U. (2016). Kesiapan Belajar Mandiri Guru Sekolah Dasar Sebagai Mahasiswa Pada Program Studi Pgsd Fkip Universitas Terbuka Self-Directed Learning Readiness of Elementary School Teacher As Student of Open University. Jurnal Pendidikan Dan Kebudayaan, 1, 279-293. http://jurnaldikbud.kemdikbud.go.id

Limbong, A. (2020). Pengaruh Model Pembelajaran Daring Akibat Pandemi Covid - 19 Terhadap Prestasi Belajar Mahasiswa UNAI pada Semester Genap 2019/2020. Jurnal TelKa, 10(2), 161-168.

Mediawati, E. (2010). PENGARUH MOTIVASI BELAJAR MAHASISWA DAN KOMPETENSI DOSEN TERHADAP PRESTASI BELAJAR. Dinamika Pendidikan, 5(2). https://doi.org/10.15294/dp.v5i2.4922

Mendikbud. (2020). Surat Edaran Mendikbud No. 35952/MPK.A/HK/2020 tentang Pembelajaran secara Daring dan Bekerja dari Rumah dalam Rangka Pencegahan Penyebaran Corona Virus Disease (Covid-19). 
Produk Hukum. https://www.kemdikbud.go.id/main/blog/2020/03/se-mendikbud-pembelajaransecara-daring-dan-bekerja-dari-rumah-untuk-mencegah-penyebaran-covid19

Ningsih, S. (2020). PERSEPSI MAHASISWA TERHADAP PEMBELAJARAN DARING PADA MASA PANDEMI COVID-19. JINOTEP, 7(2), 124-132. https://doi.org/10.17977/um031v7i22020p124

Nurgiansah, T. H., \& Dewantara, J. A. (2021). Efektivitas Pembelajaran Daring di Masa Pandemi COVID 19 bagi Mahasiswa Universitas PGRI Yogyakarta. Jurnal Basicedu, 5(1), 367-375.

Pendidikan, M., Kebudayaan, D. A. N., \& Indonesia, R. (2020). Peraturan Menteri Pendidikan Dan Kebudayaan Nomor 03 Tahun 2020 Tentang Standar Nasional Perguruan Tinggi.

Purnawinadi, I. G. (2021). Dampak pandemi covid-19 pada prestasi belajar mahasiswa keperawatan tahap akademik. Jurnal Skolastik Keperawatan, 7(1), 63-69.

Saputra, Y. N. (2020). PENGARUH KEPEMIMPINAN, MOTIVASI, DAN KOMPENSASI TERHADAP KINERJA DOSEN. EDUKASI: Jurnal Penelitian Pendidikan Agama Dan Keagamaan, 18(1), 118-135. https://doi.org/10.32729/edukasi.v18i1.603

Saputra, Y. N. (2020). Hubungan Spiritualitas dan Motivasi Belajar Mahasiswa Teologi. KURIOS (Jurnal Teologi Dan Pendidikan Agama Kristen) (Jurnal Teologi Dan Pendidikan Agama Kristen), 6(1), 2614-3135. https://doi.org/10.30995/kur.v6i1.127

Saputra, Y. N. (2021). Self-directed learning readiness mahasiswa di masa pandemi Covid-19. KURIOS (Jurnal Teologi Dan Pendidikan Agama Kristen), 7(1), 164. https://doi.org/10.30995/kur.v7i1.183

Sedarmayanti. (2009). Sumber Daya Manusia dan Produktivitas Kerja. Penerbit Mandar Maju.

Silaban, N., Citra, F. W., \& Yunita, M. (2021). Prestasi Belajar Mahasiswa Penerima Bidik Misi Selama Masa Pandemi COVID-19. JOEAI (Journal of Education and Instruction), 4(1), 1-8.

Slameto. (2010). Belajar dan Faktor-Faktor yang Mempengaruhinya. Rineka Cipta.

Widiyono, A. (2020). Efektifitas Perkuliahan Daring (Online) pada Mahasiswa PGSD di Saat Pandemi Covid 19. Jurnal Pendidikan, 8(2), 169-177.

Winata, R., Friantini, R. N., \& Astuti, R. (2021). Kemandirian belajar dan kedisipilinan belajar terhadap prestasi mahasiswa pada perkuliahan daring. Jurnal E-DuMath, 7(1), 18-26. 